\title{
PENERAPAN MODEL PEMBELAJARAN ACTIVE KNOWLEDGE SHARING PADA MATA PELAJARAN EKONOMI DI SMA
}

\author{
Fajar Rizqianna' ${ }^{1}$, Yuyun Susanti², Rizka Andhika ${ }^{3}$ \\ 1,2,3Program Studi Pendidikan Akuntansi Universitas Galuh, J.L. R. E. Martadinata No.150, Ciamis, Indonesia \\ E-mail: yuyunsusanti444@gmail.com
}

\begin{abstract}
The low learning outcomes which becomes a problem in this study is caused by various factors including the selection of appropriate learning models used by educators. The purpose of this study is to find out: 1) the learning outcomes differences of students who use active knowledge sharing learning models in the initial measurement (pretest) and final assessment (posttest) in the experimental class; 2) the learning outcomes differences of students who use conventional learning models in the initial measurement (pretest) and final assessment (posttest) in the control class; 3) the learning outcomes differences between students who use active knowledge sharing learning models and those who use conventional learning models in the initial measurement (pretest) and final assessment (posttest). The research method used to measure the improvement of student learning outcomes is Quasi Experimental Design by using the formula of $\mathrm{N}$ Gain $=$ (posttest score - pretest score) divided by (maximum score - pretest score). While to measure differences in student learning outcomes is by using t- test. The research results reveals that: 1) There are differences in learning outcomes of students who use the Active Knowledge Sharing learning model at the initial measurement (pretest) by 38.33 and the final measurement (posttest) by 83.33 with an average of N-Gain is 0.72 in a high category; 2) There are differences in learning outcomes of students who get conventional learning models at the initial measurement (pretest) by 38.15 and the final measurement (posttest) by 78.15 with an average of $N$-Gain value is 0.68 in the medium category; 3) There are differences in learning outcomes between students who get the Active Knowledge Sharing learning model and those who use conventional learning models (lectures) at the final measurement (posttest) based on the t-test obtains t-count>t-table, namely 1.69>t-table(1.67) with significant level of $5 \%$ and $d k$ by 68 .
\end{abstract}

Keywords: Learning Outcomes, Active Learning, Learning Sharing Models

\section{ABSTRAK}

Rendahnya hasil belajar merupakan masalah dalam penelitian ini. Rendahnya hasil belajar dilatarbelakangi oleh berbagai faktor diantaranya pemilihan model pembelajaran yang tepat di gunakan oleh pendidik. Tujuan penelitian ini untuk mengetahui : 1.)Perbedaan hasil belajar peserta didik yang menggunakan model pembelajaran active knowledge sharing pada pengukuran awal (pretest) dan penilaian akhir (posttest) di kelas eksperimen. 2.) perbedaan hasil belajar peserta didik yang menggunakan model pembelajaran konvensional pada pengukuran awal (pretest) dan penilaian akhir (posttest) di kelas kontrol. 3.) Perbedaan hasil belajar peserta didik yang menggunakan model pembelajaran active knowledge sharing dengan yang menggunakan model pembelajaran konvensional pada pengukuran awal (pretest) dan penilaian akhir (posttest). Metode penelitian yang digunakan untuk mengukur peningkatan hasil belajar peserta dididk adalah Quasi Experimental Design dengan menggunakan rumus N-Gain = (skor posttest - skor pretest) dibagi dengan (skor maksimum - skor pretest), sedangkan untuk mengukur perbedaan hasil belajar peserta didik menggunakan uji t. Berdasarkan hasil penelitian yang telah dilakukan, maka dapat diketahui: 1) Terdapat perbedaan hasil belajar peserta didik yang menggunakan model pembelajaran Active Knowledge Sharing pada pengukuran awal (pretest) sebesar 38,33 dan pengukuran akhir (posttest) sebesar 83,33 dengan rata-rata N-Gain bernilai 0,72 dengan kategori tinggi. 2) Terdapat perbedaan hasil belajar peserta didik yang mendapatkan model pembelajaran konvensional pada pengukuran awal (pretest) sebesar 38,15 dan pengukuran akhir (posttest) sebesar 78,15 dengan rata-rata N-Gain bernilai 0,68 dengan kategori sedang. 3) Terdapat perbedaan hasil belajar peserta didik yang mendapatkan model pembelajaran Active Knowledge Sharing dengan yang menggunakan model pembelajaran konvensional (ceramah) pada pengukuran akhir (posttest) berdasarkan uji t-test diperoleh thitung>t_tabel, yaitu 1,69>ttabel1,67 dengan taraf signifikansi 5\% dan dk sebesar 68.

Kata Kunci: Hasil Belajar, Model Pembelajaran Active Knowledge Sharing

Cara sitasi: Rizqianna, F.,Susanti, Y \& Andhika, R. Penerapan model pembelajaran active knowledge sharing pada mata pelajaran ekonomi di sma. J-KIP (Jurnal Keguruan dan IImu Pendidikan), 2 (2), 63-70. 


\section{PENDAHULUAN}

Belajar merupakan usaha sadar yang dilakukan setiap individu untuk memperoleh perubahan tingkah laku. Perubahan tingkah laku yang diperoleh melalui proses belajar secara keseluruhan meliputi berbagai macam aspek yaitu, aspek kognitif (pengetahuan), afektif (sikap), dan psikomotorik (keterampilan). Menurut Syah (2016) "belajar adalah kegiatan yang berproses dan merupakan unsur yang sangat fundamental dalam penyelenggaraan setiap jenis dan jenjang pendidikan". Setelah melakukan proses belajar, peserta didik akan mendapatkan hasil belajar.

Hasil belajar merupakan kompetensi atau kemampuan peserta didik tertentu baik dalam bidang kognitif, afektif, maupun psikomotor yang yang dicapaipeserta didik setelah mengikuti proses pembelajaran. Hal ini sejalan dengan pendapat Abdurrahman (dalam Jihad dan Haris, 2012) mengemukakan bahwa "hasil belajar adalah kemampuan yang diperoleh anak setelah melaluikegiatan belajar". Hasil belajar peserta didik dipengaruhi oleh faktori nternal dan eksternal.

Adapun hasil observasidi SMA Negeri 2 Ciamis, berdasarkan hasil ulangan harian mata pelajaran ekonomi pada semester ganjil tahun 2019/2020 peserta didik kelas X diperoleh data sebagai berikut :

Tabel 1. Nilai Ulangan Harian Kelas X IPS SMA Negeri 2 Ciamis

\begin{tabular}{|c|c|c|c|c|c|c|c|}
\hline \multirow{2}{*}{ No. } & \multirow{2}{*}{ Kelas } & \multirow{2}{*}{ KKM } & \multirow{2}{*}{ Peserta Didik } & \multicolumn{2}{|c|}{ Belum Tuntas } & \multicolumn{2}{|c|}{ Tuntas } \\
\hline & & & & Jumlah & $\%$ & Jumlah & $\%$ \\
\hline 1 & XIPS 1 & 75 & 36 & 34 & 94,44 & 2 & 5,56 \\
\hline 2 & XIPS 1 & 75 & 35 & 28 & 80 & 7 & 20 \\
\hline 3 & XIPS 1 & 75 & 36 & 32 & 88,89 & 4 & 11,11 \\
\hline \multirow[t]{2}{*}{4} & X IPS 1 & 75 & 35 & 26 & 74,29 & 9 & 25,71 \\
\hline & Jumlah & & 142 & 120 & 85 & 22 & 15 \\
\hline
\end{tabular}

Sumber : SMA Negeri 2 Ciamis

Dari data di atas dapat disimpulkan bahwa peserta didik kelas $X$ di SMA Negeri 2 Ciamis sebagian besarhasil belajar mata pelajaran Ekonomi yang dicapai kurang optimal atau belummencapai nilai KKM. Hal tersebut menunjukkan bahwa hasil belajar peserta didik di SMA Negeri 2 Ciamis masih rendah yang dibuktikan dengan presentase jumlah peserta didik yang belum tuntas sebanyak 120 pesrta didik dari 142 orang, salah satu faktor yang mempengaruhi rendahnya hasil belajar peserta didik adalah penggunaan model pembelajaran yang masih berpusat pada guru (teacher centered)tanpa adanya variasi, sehinggakurang aktifnya peserta didik dalam proses pembelajaran.

Masalah hasil belajar peserta didik yang rendah, hal ini dipengaruhi oleh beberapa faktor. Faktor-faktor yang mempengaruhi hasil belajar peserta didik yang rendah dibedakan menjadi dua faktor yaitu faktor internal dan faktor eksternal. Faktor internal yang mempengaruhi hasil belajar peserta didik yang rendah yaitu kurangnya minat belajar peserta didik, sedangkan faktor eksternalnya adalah guru yang pada umumnya masih menggunakan model pembelajaran konvensional dan bersifat satu arah, ini menyebabkan kurangnya interaksi antara peserta didik dengan peserta didik ataupun peserta didik dengan guru dalam proses pembelajaran.

Salah satu upaya untuk meningkatkan hasil belajar peserta didik adalah pemilihan model pembelajaran yang mampu membuat peserta didik lebih aktif dalam proses pembelajaran dan berdampak pada hasil belajar yang memuaskan. Selain itu model pembelajaran aktif juga menjaga perhatian peserta didik agar tetap fokus dalam proses pembelajaran dan dapat meningkatkan keaktifan, pemahaman, serta meningkatkan keberanian. Keunggulan pembelajaran aktif menurutHosnan (2014) bahwa pembelajaran aktif ini "mendorong peserta didik melakukan kegiatankegiatan belajar serta memikirkan apa yang dilakukannya untuk belajar".

Peserta didik mengalami kesulitan dalam menerima dan mempelajari materi pelajaran ekonomi, kesulitan yang dihadapi peserta didik dalam materi tersebut mungkin disebabkan oleh cara 
belajar yang kurang sesuai, dimana pada akhirnya masalah ini berdampak pada rendahnya hasil belajar peserta didik yang dilihat dari data nilai ulangan harian peserta didik, salah satu alternatif untuk meningkatkan hasil belajar peserta didik adalah dengan menerapkan model pembelajaran Active Knowledge Sharing.

Active Knowledge Sharing adalah model pembelajaran yang memberikan penekanan kepada peserta didik untuk saling berbagi pengetahuan dan membantu dalam menyelesaikan pertanyaan yang diberikan. Artinya ketika peserta didik yang tidak mampu menjawab suatu pertanyaan atau mengalami kesulitan, maka peserta didik lain yang mampu menjawab pertanyaan dapat membantu temannya untuk menyelesaikan pertanyaan yang sudah diberikan (Siberman, 2013).

\section{METODE PENELITIAN}

Metode penelitian merupakan suatu cara untuk mendapatkan data dengan tujuan dan kegunaan tertentu. Pada penelitian ini peneliti menggunakan metode eksperimen karena tujuan penelitian ini ingin mengetahui hubungan sebab-akibat antara dua variabel. Sugiyono (2013) menyatakan "penelitian eksperimen adalah penelitian yang digunakan untuk mencari pengaruh perlakuan tertentu terhadap orang lain dalam kondisi yang dikendalikan".

Pada penelitian ini peneliti menggunakan metode eksperimen karena tujuan penelitian ini ingin mengetahui hubungan sebab-akibat antara dua variabel. Desain yang digunakan dalam penelitian ini adalah Pretest-Posttest Group Design. Pada eksperimen subjek tidak dikelompokkan secara acak, tetapi peneliti menerima keadaan subjek seadanya.

Berdasarkan keterangan yang telah diuraikan sebelumnya, maka pola desainnya dapat digambarkan sebagai berikut:

Tabel 2. Desain penelitian Quasi Experimental Design dengan tipe Nonequivalent Control Group Design

\begin{tabular}{lccc}
\hline Kelas & Tes Awal & Perlakuan & Tes akhir \\
\hline Eksperimen & $O_{1}$ & $\mathrm{X}$ & $O_{2}$ \\
Kontrol & $O_{3}$ & & $O_{4}$ \\
\hline
\end{tabular}

Sumber: Sugiyono (2016)

Keterangan:

$O_{1}=$ Tes awal kelas eksperimen untuk mengetahui pengetahuan awal peserta didik

$O_{3}=$ Tes awal kelas kontrol untuk mengetahui pengetahuan awal peserta didik

$\mathrm{X}=$ Perlakuan diberikan kepada kelas eksperimen, yaitu penerapan Model Pembelajaran Active Knowledge Sharing.

$\mathrm{O}_{2}=$ Tes akhir kelas eksperimen setelah mengikuti pembelajaran dengan melakukan penerapan Model Pembelajaran Active Knowledge Sharing

$\mathrm{O}_{4}=$ Tes akhir kelas kontrol setelah mengikuti pembelajaran menggunakan model pembelajaran konvensional.

Untuk lebih jelasnya dalam pelaksanaan penelitian, penulis akan melakukan pretest terlebih dahulu pada kelas X SMA Negeri 2 Ciamis untuk mengetahui kelas mana yang akan dijadikan kelas eksperimen dan kelas kontrol. Kemudian melakukan kegiatan belajar mengajar selama kurang lebih $4 x$ pertemuan. Setelah proses belajar mengajar dilakukan, sebelum dilaksanakan posttest kelas eksperiman melakukan kegiatan dengan menggunakan model pembelajaran Active Knowledge Sharing. Sedangkan kelas kontrol setelah proses belajar mengajar 
dengan menggunakan model pembelajaran konvensional (ceramah) selesai langsung dilaksanakan posttest untuk mengetahui peningkatan hasil belajar peserta didik.

\section{HASIL DAN PEMBAHASAN}

\section{Terdapat perbedaan hasil belajar siswa yang menggunakan model pembelajaran Active Knowledge Sharing pada pengukuran awal (pretest) dan penilaian akhir (posttest) di kelas Eksperimen.}

Berdasarkan hasil penelitian terdapat perbedaan hasil belajar siswa yang menggunakan model pembelajaran Active Knowledge Sharing pada pengukuran awal (pretest) diperoleh hasil ratarata sebesar 38,43 dan penilaian akhir ( posttest) diperoleh hasil rata-rata sebesar 83,33 di kelas Eksperimen. Dengan demikian hasil belajar peserta didik terdapat perbedaan sebesar 44,90. Peningkatan hasil belajar peserta didik didukung oleh beberapa faktor antara lain, faktor fasilitas sekolah, suasana belajar dikelas, keluarga, lingkungan.

Penulis menghitung tingkat peningkatan hasil belajar peserta didik pada pretest dan posttest dengan menggunakan rumus N-Gain. Berdasarkan perhitungan rata-rata N-Gain peningkatan hasil belajar peserta didik yang menggunakan model pembelajaran Active Knowledge Sharing bernilai 0,72 dengan kategori tinggi. Setelah mengetahui peningkatan hasil belajar peserta didik, peneliti mencari tingkat perbedaan hasil belajar peserta didik. Untuk mengetahui perbedaan hasil belajar peserta didik pada pretest dan posttest dengan menggunakan uji t. Diperoleh nilai tabel sebesar 1,67 serta nilai thitung sebesar 12,44. Dengan demikian dapat disimpulkan bahwa thitung $>$ dari nilai tabel atau 12,44> dari 1,67 artinya terdapat perbedaan hasil belajar peserta didik pada pengukuran awal dan akhir pada kelas ekperimen yang menggunakan model pembelajaran Active Knowledge Sahring artinya Model Pembelajaran Active Knowledge Sharing dapat meningkatka hasil belajar peserta didik di kelas eksperimen.

Perbedaan hasil belajar peserta didik pada pengukuran awal (pretest) dan pengukuran akhir (posttest) berdasarkan hasil penelitian di lapangan disebabkan oleh peran aktif peserta didik dalam mencari jawaban atas pertanyaan yang diberikan oleh guru kepada teman sekelasnya, dan dorongan untuk saling berbagi pengetahuan dengan teman dalam menjawab pertanyaan yang diberikan oleh guru, dengan adanya keinginan untuk memecahkan masalah pembelajaran dengan cara menjawab pertanyaan dari guru, maka hasil belajar peserta didik dapat meningkat. Hal ini sejalan dengan yang diungkapkan oleh Suyadi (2013:46) bahwa "Active Knowledge Sharing adalah model pembelajaran untuk mengaktifkan peserta didik sejak awal dengan cara sharing pengetahuan. Metode ini sangat efektif untuk menarik perhatian para peserta didik pada menit-menit pertama. Selain itu, metode ini sekaligus dapat digunakan untuk mengukur tingkat pengetahuan para peserta didik mengenai tema yang akan dibahas."

Penerapan model pembelajaran Active Knowledge Sharing dapat meningkatkan keaktifan peserta didik dalam proses pembelajaran dan meningkatkan pemahaman materi peserta didik terhadap tema yang di bahas. Pada penerapan model pembelajaran ini peserta didik yang berprestasi tinggi dapa membantu temannya yang berprestasi rendah. Pada penerapan model pembelajaran Active Knowledge Sharing guru menekan dan menciptakan kerjasama antar peserta didik untuk dapat menjawab pertanyaan dan membantu temannya yang tidak bisa menjawab pertanyaan. Selain itu model pembelajaran Active Knowledge Sharing dapat meminimalisasi keterlibatan guru dalam proses pembelajaran dalam, serta memungkinkan pesrta didik untuk bekerja dengan pesrta didik lain sehingga tercipta sikap positif diantara mereka.

Adanya perbedaan hasil belajar peserta didik pada pengukuran awal (pretest) dengan hasil belajar peserta didik pada pengukuran akhir (posttest) disebabkan karena penerapan model pembelajaran Active Knowledge Sharing menitikberatkan kepada peserta didik untuk lebih aktif dalam proses belajar. Sehingga peserta didik dapat meningkatkan pengetahuan dan kemampuannya akhirnya berdampak pada peningkatan hasil belajar peserta didik. 
Terdapat perbedaan hasil belajar siswa yang menggunakan model pembelajaran konvensionalpada pengukuran awal (pretest) dan penilaian akhir ( posttest) di kelas kontrol

Berdasarkan hasil penelitian di lapangan penulis menggunakan model pembelajaran konvensional di kelas kontrol, terdapat perbedaan hasil belajar peserta didik pada penilaian awal (pretest) dan penilaian akhir(posttest). Nilai rata-rata pada penilaian awal (pretest) sebesar 38,15 sedangkan pada pengukuran akhir (posttest) diperoleh nilai rata-rata sebesar 78,15.

Peningkatan hasil belajar peserta didik di hitung dengan menggunakan rumus N-Gain. Berdasarkan perhitungan rata-rata N-Gain peningkatan hasil belajar peserta didik yang menggunakan model pembelajaran konvensionalbernilai 0,63 dengan kategori sedang. Sedangkan untuk mengetahu perbedaan hasil belajar peserta didik digunakan uji t. Diperoleh nilai tabel sebesar 1,67 serta nilai thitung sebesar 16,19 . Dengan demikian dapat disimpulkan bahwa thitung $>$ dari nilai tabel atau $16,19>$ dari 1,67 artinya terdapat perbedaan hasil belajar peserta didik pada pengukuran awal dan akhir pada kelas kontrol yang menggunakan model pembelajaran konvensionalartinya Model Pembelajaran Konvensional dapat meningkatkan hasil belajar peserta didik di kelas kontrol. Perbedaan hasil belajar peserta didik yang menggunakan metode pembelajaran konvensional dikarenakan penyampaian materi dalam model pembelajaran konvensional (ceramah) guru lebih berperan dominan, hal ini membantu peserta didik memahami materi yang disampaikan. Namun penerapan model pembelajaran ini harus ada variasi atau diselingi dengan ice breaking dengan memberikan selingan humor atau games agar peserta didik tidak merasakan bosan saat kegiatan belajar di kelas.

Model pembelajaran konvensional (ceramah) di dominasi oleh guru yang menjelaskan materi kepada peserta didik yang sifatnya satu arah, namun dengan begitu peserta didik dapat fokus terhadap satu sumber yaitu guru. Setelah guru menjelaskan, akan ada pertanyaan dari peserta didik apabila ada materi yang belum dipahami kemudian akan ada latihan untuk mengukur pemahaman peserta didik terhadap materi yang telah disampaikan. Hal ini sejalan dengan yang dipaparkan oleh Djamarah (2010:97), "metode ceramah adalah metode yang boleh dikatakan metode tradisional karena sejak dulu metode ceramah ini telah digunakan sebagai alat komunikasi lisan antara guru dengan anak didik dalam proses belajar dan mengajar. Pembelajaran model konvensional ditandai dengan ceramah yang diiringi dengan penjelasan, serta pembagian tugas dan latihan."

Penerapan model pembelajaran konvensionaldapat meningkatkan pemahaman peserta didik terhadap tema yang di bahas. Pada penerapan model pembelajaran ini diharapkan peserta didik memahami apa yang disampaikan oleh guru. Model pembelajaran konvensionalguru berperan dominan di dalam kelas. Guru menjelaskan materi yang dibahas dan peserta didik memperhatikan. Apabila ada yang tidak dipahami oleh peserta didik, peserta didik akan bertanya dan guru menjawab pertanyaan yang diberikan oleh peserta didik.

Adanya perbedaan hasil belajar peserta didik pada pengukuran awal (pretest) dengan hasil belajar peserta didik pada pengukuran akhir (posttest) disebabkan karena penggunaan model pembelajaran konvensionalmenitikberatkan guru menjelaskan materi dalam proses belajar. Sehingga peserta didik dapat meningkatkan pengetahuannya akhirnya berdampak pda peningkatan hasil belajar peserta didik.

Terdapat perbedaan hasil belajar siswa yang menggunakan model pembelajaran Active Knowledge Sharing dengan yang menggunakan model pembelajaran konvensional (ceramah) pada pengukuran akhir (posttest)

Berdasarkan hasil pengujian hipotesis diketahui bahwa model pembelajaran Active Knowledge Sharing yang diterapkan di kelas eksperimen lebih unggul dan menghasilkan nilai akhir yang lebih tinggi dibandingkan dengan model pembelajaran konvensionalpada kelas kontrol. Hal ini dibuktikan dengan diperoleh data pengukuran akhir (posttest) kelas eksperimen denganjumlah 
sampel 34 peserta didik, nilai tertinggi sebesar 100,00 dan nilai terendah 40,00 nilai rata-rata diperoleh sebesar 83,33. Sedangkan pada pengukuran akhir (posttest) kelas kontrol dengan jumlah sampel 36 peserta didik, diperoleh nilai tertinggi 100 dan nilai terendah sebesar 60 , nilai rata-rata diperoleh sebesar 78,15. Perbedaan Nilai N-Gain kelas Eksperimen sebesar 0,72 dengan kategori tinggi sedangkan nilai $\mathrm{N}-\mathrm{Gain}$ kelas kontrol sebesar 0,63 dengan kategori sedang.

Berdasarkan pengujian hipotesis bahwa ada perbedaan hasil belajar peserta didik yang menggunakan model pembelajaran Active Knowledge Sharing dengan yang menggunakan model pembelajaran konvensional (ceramah) pada mata pelajaran ekonomi kompetensi dasar konsep manajemen di kelas X IPS 1 yaitu sebagai kelas eksperimen dan di kelas X IPS 2 sebagai kelas kontrol. Hal ini diperkuat dengan pengujian $t$-test yang memperoleh nilai thitung sebesar 1,69 sedangkan nilai tabel 1,67 dengan nilai derajat kebebasan (dk) sebesar 68 dengan taraf kepercayaan $95 \%$ atau taraf signifikansi 0,05 . Hal tersebut menunjukan bahwa thitung $>t_{\text {tabel }}(1,69>1,67)$. Berdasarkan hasil pengujian hipotesis dapat disimpulkan bahwa model pembelajaran Active Knowledge Sharing lebih unggul dalam meningkatkan hasil belajar peserta didik daripada model pembelajaran konvensional. Dalam penerapan model pembelajaran Active Knowledge Sharing peserta didik lebih aktif dalam kegiatan belajar di kelas dibandingkan dengan kegiatan belajar yang menggunakan model pembelajaran konvensional (ceramah). Karena pada penerapan model pembelajaran Active Knowledge Sharing peserta didik dituntuk untuk berperan aktif di dalam proses pembelajaran, selain itu peserta didik diminta untuk saling membantu satu sama lain dalam menjawab pertanyaan sehingga pengetahuan mereka bertambah. Hal ini sejalan dengan pendapat dari Menurut Siberman (2013) menyatakan bahwa keunggulan model pembelajaran Active Knowledge Sharingadalah sebagai berikut:

1 Strategi ini dapat menjadikan peserta didik aktif dalam mencari jawaban yang diberikan oleh guru.

2 Untuk melatih peserta didik agar dapat bekerja sama dengan temannya.

3 Menambah pengetahuan peserta didik, peserta didik dapat meminta bantuan kepada peserta didik lain untuk membantu menjawab pertanyaan yang tidak bisa dijawab sehingga peserta didik yang pertamanya tidak mengetahui sama sekali jawaban dari pertanyaan yang diberikan guru menjadi tahu.

Pada penerapan model pembelajaran konvensional sebaliknya dari penerapan model pembelajaran Active Knowledge Sharing. Melalui penerapan model pembelajaran konvensional peserta didik menjadi pasif selama proses pembelajaran karena proses interaksi cenderung satu arah. Model pembelajaran konvensional tidak menuntut siswa menjadi aktif selama proses pembelajaran, ada peserta didik yang memeperhatikan namun banyak juga siswa yang tidak memperhatikan, tertidur dan merasa bosan sehingga membuat konsentrasi terganggu dan akhirnya tidak memahami materi yang disampaikan oleh guru.

Hal ini sejalan dengan pendapat Djamarah dan Zain (2010) yang mengemukakan bahwa kelemahan model pembelajaran konvensional yaitu :

1) Mudah menjadi verbalisme

2) Yang visual menjadi rugi, dan yang auditif (mendengarkan) yang benar-benar menerimanya.

3) Bila selalu digunakan dan terlalu digunakan dapat membuat bosan.

4) Keberhasilan sangat bergantung apada siapa yang menggunakannya

5) Cenderung membuat siswa pasif.

Model pembelajaran Active Knowledge Sharing menitik beratkan peserta didik untuk berperan aktif dalam proses belajar, sdeangkan model pembelajaran konvensional (ceramah) guru lebih mendominasi pada kegiatan belajar mengajar di dalam kelas. Dengan demikian penerapan model pembelajaran Active Knowledge Sharing dengan model pembelajaran konvensional (ceramah) pada mata pelajaran ekonomi di kelas X SMA Negeri 2 Ciamis, masing-masing memiliki peran yang baik dalam peningkatan hasil belajar peserta didik. Namun hasil belajar peserta didik 
yang mendapatkan model pembelajaran Active Knowledge Sharing lebih tinggi dibandingkan dengan hasil belajar peserta didik yang mendapatkan model pembelajaran konvensional (ceramah).

\section{KESIMPULAN}

Berdasarkan hasil penelitian dan pembahasasn tentang model pembelajaran Active Knowledgr Sharing di SMA Negeri 2 Ciamis, dapat ditarik kesimpulan sebagai berukut:

1. Terdapat perbedaan hasil belajar peserta didik yang menggunakan model pembelajaran active knowledge sharing dengan kategori tinggi.

2. Terdapat perbedaan hasil belajar peserta didik yang menggunakan model pembelajaran konvensional dengan kategori sedang.

3. Terdapatperbedaan hasil belajar peserta didik yang menggunakan model pembelajaran active knowledge sharing dengan yang menggunakan metode konvensional(ceramah).

\section{REKOMENDASI}

Berdasarkan hasil penelitian dan pembahasan, penulis menyarankan:

1. Model pembelajaran active knowledge sharing diterapkan pada kegiatan pembelajaran Ekonomi di SMA dalam upaya meningkatkan hasil belajar peserta didik sebagai bekal dalam menganalisis konsep manajemen.

2. Hendaknya guru dapat menggunakan model pembelajaran Active Knowledge Sharing agar dapat lebih meningkatkan hasil belajar peserta didik dan tujuan pembelajaran dapat dicapai dengan baik.

3. Bagi peneliti selanjutnya diharapkan dapat melakukan penelitian lebih lanjut mengenai model pembelajaran active knowledge sharing untuk dikombinsikan dengan metode atau model pembelajaran tipe yang berbeda.

\section{UCAPAN TERIMA KASIH}

Menyatakan ucapan terimakasih kepada pihak-pihak yang telah membantu dalam kegiatan penelitian yang dilakukan. Pihak-pihak tersebut, misalnya lembaga atau perorangan yang telah memberikan beasiswa, sponsor, dana penelitian, sarana dan prasarana penelitian. Nama orang yang membantu dalam penelitian harus ditulis lengkap dengan gelar yang dimilikinya.

\section{DAFTAR PUSTAKA}

Arikunto, S. 2014. Prosedur Penelitian: Suatu Pendekatan Praktik. Jakarta: PT. Rineka Cipta.

Arikunto, S. 2012. Dasar-Dasar Evaluasi Pendidikan. Jakarta: Bumi Aksara.

Djamarah, S, B \& Aswan, Z. 2010. Strategi Belajar Mengajar. Jakarta: Rineka Cipta.

Jihad, A \& Haris, A. 2012. Psikologi Belajar. Jakarta: Raja Grafindo Persada.

Lestari, K, E \& Yudhanegara, M. R. 2017. Penelitian Pendidikan Matematika. Bandung : PT. Refika Aditama.

Silberman, M. L. 2013. Active Learning 101 Cara Belajar Peserta didik Aktif. Bandung: Nusamedia.

Sugiyono. 2013. Metode Penelitian Pendidikan (Pendekatan Kuantitatif, Kualitatif dan R\&D). Bandung: CV. Alfabeta.

Suyadi. 2013. Strategi Pembelajaran Pendidikan Karakter. Bandung: PT Remaja.

Syah, M. 2016. Psikologi Belajar. Bandung: PT Remaja Rosdakarya. 
